\section{Candidates' science lessons}

\section{São Paulo}

TIE support of science and technology has not been a conspicuous topic in speeches by candidates in the Brazilian presidential election, due on 15 November. But several national institutions have submitted to the candidates a 45-point document reminding them of the importance of science to Brazil's development, and making suggestions for the future.

Although it is meant to be optimistic, the tone of the document gives a measure of the despair felt by the scientific community. It tells the candidates, for example, which government bodies deal with research funding, as if George Bush or Michael Dukakis had had to be told in last year's US election campaign what the National Science Foundation is and what it does.

The report comes from the federal government's Special Secretariat for Science and Technology, with the support of the Brazilian Academy of Science, the Council of Rectors of Brazilian Universities and the influential Federation of Industries of the State of São Paulo, the country's most industrialized state.

Notably absent from the signatories was the Brazilian Society for the Progress of Science (SBPC), the biggest association of scientists; its president, Ennio Candotti, said that even though he agrees with most of what the report says, it was not "politically convenient" to sign it, because of its governmental origins.

SBPC is unhappy with the present government's treatment of science. At the beginning of President José Sarney's term, a new Ministry for Science and Technology was created, and there was a promise to increase research and development spending to 2 per cent of gross national product (GNP). But with Sarney's term due to expire in March 1990, spending on research and development stands at only 0.7 per cent of GNP, and the Science and Technology Ministry has been replaced by the Special Secretariat for Science and Technology, a body with cabinet rank, but without the status of a ministry. But SBPC's criticisms are partially echoed in the document, which is why Candotti has not condemned it.

Thus the report admits some problems that scientists have been complaining of for years. Bureaucratic complexity in foreign currency exchange, along with laws restricting the import of items for

\section{Correction: German telescopes}

There have been no funds set aside for the building of a large new telescope in West Germany, contrary to the first paragraph of an article in Nature last week (Nature 341, 177, 1989). One of the telescope designers mentioned is Gerhard Schnur of the University of Bochum. which a Brazilian equivalent exists, have made it almost impossible to make use of foreign funds for research. Brazil is now negotiating the second phase of a World Bank loan that would provide $\$ 330$ million for research, with an equal sum to be provided by the federal government, over the next five years. This would be an enormous boost for university research, but only if the money actually reaches scientists.

The suggestions in the document include new tax incentives for private companies investing in research and development, and better integration of university research with industry. This is a theme particularly dear to the secretary of science and technology, Décio Leal de Zagottis, former director of the Escola Politécnica, São Paulo's engineering school.

The initiative now rests with the presidential candidates. According to press reports, the leading candidate, Fernando Collor de Mello, plans to reduce the number of ministries from 23 to 10 , but has apparently decided to retain the Special Secretariat for Science and Technology, rather than merging it with a bigger ministry. But Brazilian scientists will not lose sleep over the fate of a government department: what they fear most is Brazilian politicians' habit of dismantling the work of their predecessors, making empty any pretence of a long-term policy for research.

Ricardo Bonalume Neto

INDIA

\section{Restriction venture}

\section{New Delhi}

INDIA has launched its first venture capital company to make restriction enzymes. Bangalore Genei Private Ltd has been set up by Dr P. S. Babu, a theoretical physicist-turned-molecular biologist, and Dr K. Prasad, an immunologist, both of whom have been associated with the Indian Institute of Science, Bangalore. A large part of the funding for the company comes from the Technology Development and Information Company of India.

The new company will obtain the knowhow for the manufacture of the enzymes from Astra Research Centre, Bangalore, which carries out research in medical biotechnology and is developing diagnostic kits for a variety of tropical diseases. The Centre for Genetic Engineering will also assist the new company.

Restriction enzymes are currently being imported by individual laboratories and in bulk quantities by the CSIR Centre for Biochemicals, New Delhi. The new company will initially make the more important and commonly used restriction enzymes.

K. S. Jayaraman
Observation satellite flies first hurdle

\section{Paris}

DESPITE financial worries within the member states of the European Space Agency (ESA), the next-generation European remote-sensing satellite (ERS-2) last week survived an early round of discussion of its fate. There was concern within ESA that the satellite would have to be cancelled or postponed, as its major backers Britain, France and West Germany were rumoured to be unenthusiastic. The three nations are expected to provide about 65 per cent of the costs. But at the Earth Observation programme board meeting last week, member states supported a recommendation that the satellite programme should begin.

In the corridors of ESA, reactions to the news are restrained, as the go-ahead for ERS-2 (or EEMS - European environment monitoring satellite as it is known within ESA) now depends on the decision of the ESA council at its October or December meeting. And it is only then, if a decision to proceed is agreed, that member states will be asked to commit themselves to a budget.

The uncertainty over ERS-2 has nevertheless emphasized budget difficulties within ESA. Having committed themselves in November 1987 to the costly Columbus programme, the Hermes space shuttle and Ariane-5 launcher, member states have little money left for the optional 'user programmes', such as Earth observation, and microgravity research. France, having agreed to finance its own Spot remotesensing programme to the end of the century (see Nature 340,$583 ; 1989$ ), was expected to give ERS-2 only a lukewarm reception. Similarly, West Germany agreed only a third of the increase requested in next year's space budget (see Nature 340,$179 ; 1989$ ), putting both ERS-2 and the data-relay satellite, DRS, under threat.

The US Landsat and French Spot remotesensing satellites do not have the same goals or capabilites as ERS, whose synthetic aperture radar allows images to be collected at night and through cloud cover, while a radar altimeter measures peaks and troughs in the ocean surface to within a few centimetres. ERS-2 should cost "about 51 per cent" of the total costs of ERS-1, according to a discussion document, and is needed to provide data continuity between ERS-1, due for launch in October next year and the polar platform scheduled for 1997. If ERS-2 does not go ahead immediately, say sources within ESA, not only will this continuity be lost, but the satellite will become more difficult and expensive to build if existing teams disband. A novel global-ozone measuring experiment it is to carry will also be threatened.

Peter Coles 